\title{
Factors influencing the appearance of spider (Araneae) and beetle (Coleoptera) assemblages in nests of great reed warbler Acrocephalus arundinaceus
}

\author{
Thomas O. MÉrő ${ }^{1,2}$, Maja JAnjatović ${ }^{2}$, Roland Horváth ${ }^{1}$, Katarina MrkobraD ${ }^{3}$ \\ \& Antun ŽULJEvić ${ }^{2}$ \\ ${ }^{1}$ Department of Ecology, Faculty of Sciences and Technology, University of Debrecen, Egyetem tér 1, H-4032 Debrecen, \\ Hungary; e-mail: thomas.oliver.mero@gmail.com \\ ${ }^{2}$ Nature Protection and Study Society - NATURA, Milana Rakića 20, SRB-25000 Sombor, Serbia; e-mail: \\ antun.zuljevic@gmail.com \\ ${ }^{3}$ Faculty of Philosophy, University of Belgrade, Cika Ljubina 18-20, SRB-11000 Belgrade, Serbia, e-mail: \\ katherinemkb@gmail.com
}

\begin{abstract}
The appearance of spider (Araneae) and beetle (Coleoptera) assemblages found in nests of great reed warbler Acrocephalus arundinaceus was studied, firstly to investigate breeding success and the amount of precipitation as potential factors which might affect the abundance and species richness of both groups. In addition, we compared the diversity of spider and beetle assemblages between nests found in different reed habitats, and considered the position of nests (above water or dry ground). In this study we selected five different randomly chosen reed habitats: two mining ponds, two small canals and one large canal. Great Reed Warbler nests were collected either shortly after fledging, or after the clutch had failed. Altogether, 12 species of spider and 19 species of beetle were collected. In both groups there was no significant difference in abundance between successful, lost and cuckoo-parasitized nests; however, there was a significant difference in species richness between the three nest categories in spider assemblages, which was not the case in beetle assemblages. The amount of precipitation did not affect beetle or spider abundance; only the species richness of spiders showed significant growth. Furthermore, we found no significant relationship between vegetation cover and the species richness and abundance of spiders and beetles. The diversity of both groups differed significantly according to reed habitat: beetle assemblages were most diverse by the large canal and spiders at the mining ponds.
\end{abstract}

Key words: abundance; species richness; diversity; breeding success; great reed warbler; precipitation amount; Poisson model

\section{Introduction}

Several European papers have reported the presence of arthropods (e.g., Pseudoscorpionida, Acari, Araneae, Coleoptera, Diptera) in bird nests (Jurík \& Šustek 1978; Sustek \& Jurík 1980; Šustek \& Hornychová 1983; Krištofík et al. 1993, 1994, 1995, 2003, 2005, 2007, 2009; Šustek \& Krištofík 2002, 2003). Arthropods have been investigated predominantly in the nests of passerines (Jurík \& Šustek 1978; Šustek \& Jurík 1980; Šustek \& Hornychová 1983; Krištofík et al. 1993, 1994, 1995, 2005, 2007; Šustek \& Krištofík 2002, 2003), in the nests of birds of prey (Dražina \& Špoljar 2009; Krištofík et al. 2009) and also in owl nests (Krištofík et al. 2003; Majka et al. 2006). However, only a few papers have discussed the species composition and abundance of arthropods in the nests of reed-nesting passerines (Krištofík et al. 2001, 2005) and only two studies have reported results regarding arthropods in the nests of the great reed warbler Acrocephalus arundinaceus L., 1758 (Gajdoš et al. 1991; Krištofík et al. 2001). Krištofík et al. (2001) studied mites (Acari), beetles (Coleoptera) and fleas (Siphonaptera) in great reed warbler nests.

It is generally known that the diversity and abundance of arthropods vary from season to season with weather conditions, i.e. precipitation (Finnamore et al. 1998; Bang \& Faeth 2011), temperature (Finnamore et al. 1998; Logan et al. 2006; Antunes et al. 2008; Touloumis \& Stamou 2009) and humidity (Finnamore et al. 1998; Touloumis \& Stamou 2009). These environmental variables also affect the species composition and abundance of arthropods in bird nests (la Puente et al. 2010).

The great reed warbler prefers strong, tall and dense reed Phragmites australis (Cav.) Trin. in a variety of water habitats (Cramp 1998; Mérő \& Žuljević 2009); this species exclusively uses reed edges, mainly those adjacent to water (Leisler 1981; Nilsson \& Persson 1986; van Der Hut 1986; Graveland 1998; Prokešová \& Kocian 2004). Weather conditions can have a considerable influence on the breeding success of the great reed warbler (Beier 1981; Fischer 1994). We already 
Table 1. Coordinate and size of sampling area given with detailed vegetation cover.

\begin{tabular}{|c|c|c|c|c|c|}
\hline & MP1 & MP2 & $\mathrm{SC} 1$ & $\mathrm{SC} 2$ & $\mathrm{LC}$ \\
\hline UTM coordinate* & CR 5722 & CR 4788 & CR 5753 & CR 4802 & CR 5676 \\
\hline \multirow[t]{2}{*}{ Size of sampling area } & $1.3 \mathrm{ha}$ & 0.7 ha & $2.0 \mathrm{~km}$ & $1.0 \mathrm{~km}$ & $1.0 \mathrm{~km}$ \\
\hline & \multicolumn{5}{|c|}{ Vegetation cover of banks (\%) } \\
\hline Phragmites australis & 90 & 60 & 75 & 90 & 80 \\
\hline Typha angustifolia & 10 & 40 & 0 & 0 & 12 \\
\hline Carex sp. & 0 & 0 & 0 & 9 & 7 \\
\hline Other herb & 0 & 0 & 24 & 0 & 0 \\
\hline Woods & 0 & 0 & 1 & 1 & 1 \\
\hline
\end{tabular}

Explanations: $*$ UTM coordinates are given on $1 \times 1 \mathrm{~km}^{2}$ precision

Table 2. The pooled precipitation amount into three ten day periods for May, June and July, 2009.

\begin{tabular}{lrrr}
\hline & \multicolumn{2}{c}{ Precipitation amount (mm) } \\
\cline { 2 - 4 } Time interval & May & June & July \\
\hline First ten days period & 103.2 & 6.2 & 22.7 \\
Second ten days period & 7.4 & 15.4 & 6.2 \\
Third ten days period & 37.4 & 80.9 & 0.0 \\
\hline Total & 148.0 & 102.5 & 28.9 \\
\hline
\end{tabular}

possess some information about Coleoptera fauna in great reed warbler nests (Krištofík et al. 2001), but data on Araneae fauna in great reed warbler nests are poor (Gajdoš et al. 1991). Furthermore, there is no available information about changes in diversity of both groups in great reed warbler nests. The aims of this study were: (1) to record the species composition of spider and beetle fauna in great reed warbler nests, (2) to define their abundance and species richness in relation to the breeding success of great reed warbler, the amount of precipitation and nest position, (3) to check the relationship between vegetation cover and the species richness and abundance of spiders and beetles, and (4) to present the differences in diversity of both groups between different reed habitats.

\section{Material and methods}

The study sites are located in the town of Sombor $\left(1178 \mathrm{~km}^{2}\right)$ in the northern Serbian province of Vojvodina. The average elevation is about $89 \mathrm{~m}$ a.s.l.; Sombor is a typical lowland area with a semi-dry continental climate, where the mean annual precipitation is about $590 \mathrm{~mm}$ (400-900 mm). The mean annual temperature is $10.7^{\circ} \mathrm{C}$; July is the warmest month with a mean monthly temperature of $21.1^{\circ} \mathrm{C}$ and January is the coldest, with a mean monthly temperature of $0.8^{\circ} \mathrm{C}$ (Đukanović 1970; Tomić 1996). We selected five different randomly chosen water habitats (two mining ponds (MP), two small canals (SC) and one large canal (LC) (Table 1): (1) Bager Pond (MP1) is located in the suburban area of the northern periphery of Sombor (Table 1). In summer the water level decreases rapidly because of intensive evapotranspiration. MP1 is surrounded by crop fields and grasslands. (2) Mining pond Pista (MP2) is surrounded by croplands, where corn and wheat were cultivated in 2009. During the breeding season the water level depends on the intensity of evapotranspiration. (3) Severna Mostonga (SC1) is a part of the network of small canals in the municipality. The sampling area is surrounded by meadows, crop fields and a small settlement. (4) Kígyós (SC2), once a small river, is nowadays also classified as a small canal surrounded by crop fields. 5) Veliki bački canal - Lugovo (LC) is a section of a large canal which is part of the Danube-Tisza-Danube hydro-system (Table 1). The banks of LC are generally rich in reed vegetation. On both sides of the canal is a forest belt with young trees.

Nests $(n=40)$ were collected between June 4 and July 31, 2009. Searches for nests were carried out on both sides of the canals and throughout the whole area of ponds. Nests of the great reed warbler were regularly checked every five days during the entire breeding season. We recorded the breeding success of the nests (successful, lost, parasitized by cuckoo Cuculus canorus L., 1758) and their height above the ground or water. Nests were collected two or three days after young had fledged, or when the clutch had failed. Previously extracted nests were treated with ether. Arthropods were conserved in ethanol. The "Zapadna Bačka" Water Management Company from Sombor, provided data about the amount of daily precipitation for May, June and July 2009, as measured by the meteorological station in Sombor. We pooled the daily precipitation amount into three ten-day periods for each month (Table 2).

We used a general linear model (GLM) to compare the abundance of spiders and beetles between nests with different breeding success, using Poisson distribution with log link function and over-dispersion (Pearson Chi-square). In the case of species richness we used Student's $t$-test for comparison. Furthermore, for each nest we calculated the amount of precipitation per capita for the whole of its existence (from the date the nest was found until it was collected). Then, using Spearman correlation, we checked the relationship between the amount of precipitation and the species richness and abundance of both groups. We also 
Table 3. Abundance, share and the number of inhabited nests per spider species.

\begin{tabular}{|c|c|c|c|}
\hline Family / Species & Abundance (n) & Share $(\%)$ & Inhabited nests $(\mathrm{n})$ \\
\hline \multicolumn{4}{|l|}{ Araneidae } \\
\hline Larinioides suspicax (O. P.-Cambridge, 1876) & 1 & 0.7 & 1 \\
\hline \multicolumn{4}{|l|}{ Clubionidae } \\
\hline Cheiracanthium sp. & 2 & 1.5 & 1 \\
\hline Clubiona phragmitis (C.L. Koch, 1843) & 1 & 0.7 & 1 \\
\hline Clubiona sp. & 32 & 23.5 & 10 \\
\hline \multicolumn{4}{|l|}{ Thomisidae } \\
\hline Philodromus pulchellus Lucas, 1846 & 1 & 0.7 & 1 \\
\hline Philodromus sp. & 2 & 1.5 & 1 \\
\hline Xysticus sp. & 8 & 6.0 & 6 \\
\hline \multicolumn{4}{|l|}{ Linyphiidae } \\
\hline Donacochara speciosa (Thorell, 1875) & 1 & 0.7 & 1 \\
\hline Linyphia sp. & 3 & 2.2 & 3 \\
\hline \multicolumn{4}{|l|}{ Salticidae } \\
\hline Heliophanus auratus C.L. Koch, 1835 & 2 & 1.5 & 2 \\
\hline Heliophanus sp. & 68 & 50.0 & 13 \\
\hline Marpissa sp. & 7 & 5.2 & 3 \\
\hline Myrmarachne formicaria (De Geer, 1778) & 1 & 0.7 & 1 \\
\hline Salticidae sp. & 3 & 2.2 & 3 \\
\hline Sitticus sp. & 1 & 0.7 & 1 \\
\hline Synageles venator (Lucas, 1836) & 3 & 2.2 & 2 \\
\hline Total & 136 & 100.0 & \\
\hline
\end{tabular}

used Spearman correlation to see if there were any connections between vegetation cover and the species richness and abundance of both groups. The diversity of each group per study site was presented with the Shannon-Wiener diversity index. We used Student's $t$-test to compare diversity values between different reed habitats and nests in different positions. Statistical analyses were calculated in the $\mathrm{R}$ statistical environment software package (version 2.13.0, $\mathrm{R}$ Development Core Team 2011).

\section{Results and discussion}

Altogether we collected 233 individuals of spider $(n=136$, five families; Table 3$)$ and beetle $(n=97,12$ families; Table 4). The most abundant spider species was Heliophanus sp. $(n=68$; Table 3$)$, while Scirtes hemisphaericus (L., 1767) was the most common beetle species $(n=20$; Table 4$)$. Of a total of 49 arthropod species found in nests, the share of spiders (12 species) and beetles (19 species) was $63 \%$. In a Slovakian study $32(n=309)$ species of beetles were collected in great reed warbler nests (Krištofík et al. 2001). Only two genera (Acupalpus sp., Philonthus sp.) and one species Adrastus pallens (F., 1792) - were found in both studies, in Krištofík et al. (2001) and in this paper. It is possible that the cause for the considerable difference in the species composition of beetles is caused by the great distance between the two study sites. Gajdoš et al. (1991) found a total of 52 spider species $(n=747)$ in 299 nests of 29 bird species. In the nests of the great reed warbler they found only one species (Linyphiinae, $n=1)$. It is also important to mention that the sample size of Gajdoš et al. (1991) was very low; they collected from only one great reed warbler nest. As for the position of nests, our study showed that $25 \%$ of spider species occupied both nests above dry ground and wa-

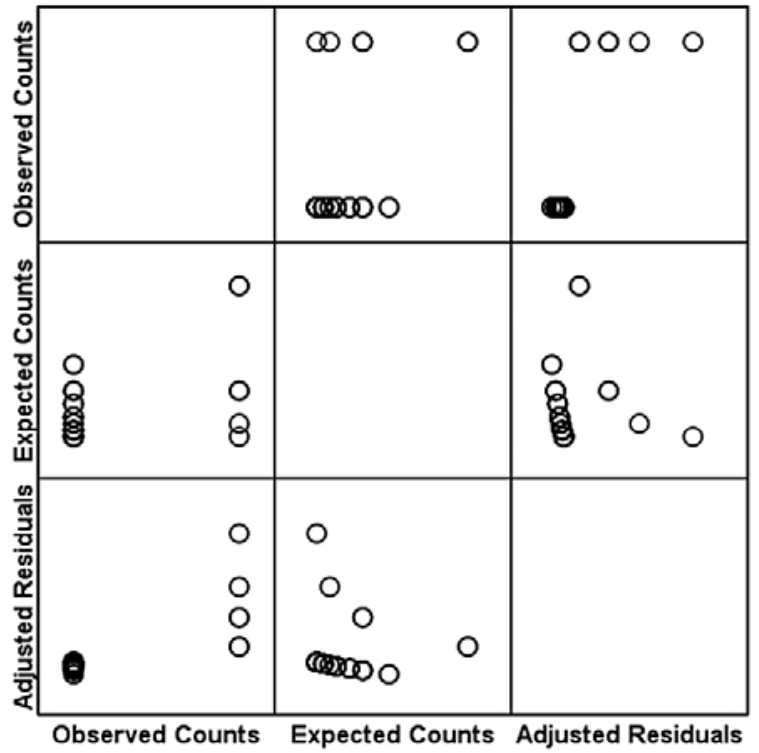

Fig. 1. Poisson model of the abundance of spider assemblages in nests with different breeding success (Pearson Chi-square with Poisson distribution).

ter, while in the case of beetles this value increased to $40 \%$.

The abundance of spider and beetle assemblages showed no significant difference between nests with different breeding success (Pearson Chi-square, spiders $\chi_{39}^{2}=54.000, P=0.056$, Fig. 1 ; beetles $\chi_{12}^{2}=8.850$, $P=0.716$, Fig. 2). It seems that the presence or nonpresence of nestlings in nests does not affect the abundance of both groups. The abundance of spider and beetle assemblages did not show a significant relationship with the amount of precipitation (spiders: Spearman, $\mathrm{rho}_{38}=0.26, P=0.1148$; beetles: $\mathrm{rho}_{38}=0.09$, 
Table 4. Abundance, share and the number of colonized nests per beetle species.

\begin{tabular}{|c|c|c|c|}
\hline Family / Species & Abundance (n) & Share $(\%)$ & Inhabited nests (n) \\
\hline \multicolumn{4}{|l|}{ Carabidae } \\
\hline Acupalpus meridianus (L., 1761) & 2 & 2.1 & 2 \\
\hline Leistus ferrugineus (L., 1758) & 4 & 4.1 & 4 \\
\hline \multicolumn{3}{|l|}{ Hydrophyllidae } & 1 \\
\hline $\begin{array}{l}\text { Hydrophyllidae sp. } \\
\text { Staphylinidae }\end{array}$ & 3 & 3.1 & 3 \\
\hline Philonthus quisquiliarius (Gyllenhal, 1810) & 12 & 12.4 & 6 \\
\hline Stenus palustris (Erichson, 1839) & 3 & 3.1 & 2 \\
\hline $\begin{array}{l}\text { Hygronoma dimidiata (Gravenhorst, 1806) } \\
\text { Attelabidae }\end{array}$ & 2 & 2.1 & 2 \\
\hline $\begin{array}{l}\text { Attelabidae sp. } \\
\text { Rhynchitidae }\end{array}$ & 1 & 1.0 & 1 \\
\hline $\begin{array}{l}\text { Neocoenorrhinus sp. } \\
\text { Elateridae }\end{array}$ & 1 & 1.0 & 1 \\
\hline Adrastus pallens (F., 1792) & 1 & 1.0 & 1 \\
\hline $\begin{array}{l}\text { Adrastus sp. } \\
\text { Anthribidae }\end{array}$ & 1 & 1.0 & 1 \\
\hline $\begin{array}{l}\text { Anthribidae sp. } \\
\text { Byturidae }\end{array}$ & 1 & 1.0 & 1 \\
\hline Byturus aestivus (Scriba, 1790) & 1 & 1.0 & 1 \\
\hline Byturus sp. & 9 & 9.3 & 5 \\
\hline \\
\hline Meligethes sp. & 5 & 5.2 & 4 \\
\hline \multicolumn{4}{|l|}{ Helodidae } \\
\hline Microcara testacea (L., 1767) & 5 & 5.2 & 1 \\
\hline $\begin{array}{l}\text { Scirtes hemisphaericus (L., 1767) } \\
\text { Silphidae }\end{array}$ & 20 & 20.6 & 3 \\
\hline $\begin{array}{l}\text { Silpha carinata Herbst, } 1783 \\
\text { Throscidae }\end{array}$ & 2 & 2.1 & 2 \\
\hline $\begin{array}{l}\text { Throscidae sp. } \\
\text { Chrisomelidae }\end{array}$ & 3 & 3.1 & 1 \\
\hline Pachnephorus sp. & 17 & 17.5 & 6 \\
\hline Total & 97 & 100.0 & \\
\hline
\end{tabular}

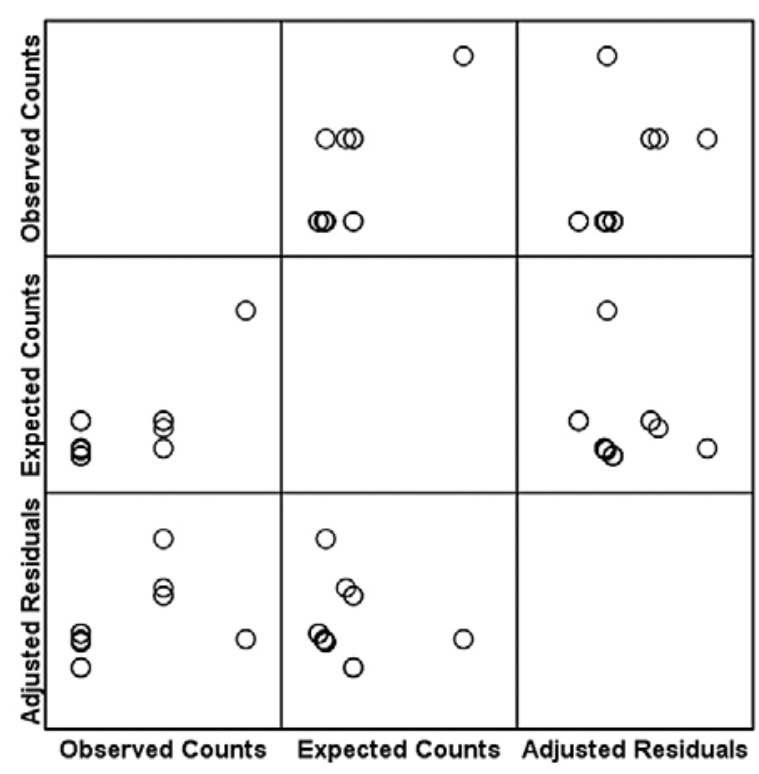

Fig. 2. Poisson model of the abundance of beetle assemblages in nests with different breeding success (Pearson Chi-square with Poisson distribution).

$P=0.5657)$. Contrary to our results, other investigations in which spiders (Carrel 2001; Rodrigues et al.
2008) and beetles (Orozco \& Perez 2008; Grimbacher \& Stork 2009) were studied found that the amount of precipitation influenced their abundance.

The species richness of spider assemblages differed significantly between the three groups of nests (Student's $t$-test, $t_{2}=5.00, P=0.0377$ ), while in the case of beetle assemblages the difference in species richness was not significant $\left(t_{2}=2.60, P=0.1217\right)$. The species richness of spiders showed a significant relationship with the amount of precipitation, while beetle assemblages did not (spiders: $\mathrm{rho}_{38}=0.40, P=0.0124$; beetles: $\mathrm{rho}_{38}=0.18, P=0.2741$. We assume that spiders actively colonize nests containing higher humidity. Finnamore et al. (1998) also reported that humidity influences the variability of arthropod species assemblages.

We did not find any significant relationship between vegetation cover and spider and beetle abundance (spiders: $\mathrm{rho}_{27}=-0.092, P=0.6467$; beetles: rho $_{31}=0.308, P=0.0914$ ) Furthermore, there was also no significant correlation between vegetation cover and species richness in both groups (spiders: $\mathrm{rho}_{27}=-0.197$, $P=0.3233$; beetles: $\left.\mathrm{rho}_{31}=0.103, P=0.5807\right)$. However, other studies pointed out a significant relationship between vegetation cover and spider and beetle assem- 
Table 5. Abundance, species richness, Shannon-Wiener diversity of both beetles and spiders.

\begin{tabular}{|c|c|c|c|c|c|c|}
\hline Group & Parameters & MP1 & MP2 & $\mathrm{SC} 1$ & $\mathrm{SC} 2$ & $\mathrm{LC}$ \\
\hline \multirow{3}{*}{ Beetles } & Abundance & 32 & 5 & 31 & 4 & 25 \\
\hline & Species richness & 8 & 5 & 8 & 4 & 11 \\
\hline & Shannon-Wiener diversity & 1.5 & 1.6 & 1.6 & 1.4 & 2.2 \\
\hline \multirow{3}{*}{ Spiders } & Abundance & 22 & 29 & 40 & 13 & 32 \\
\hline & Species richness & 11 & 5 & 6 & 2 & 6 \\
\hline & Shannon-Wiener diversity & 2.2 & 0.8 & 1.0 & 0.4 & 0.9 \\
\hline
\end{tabular}

blages (Bonte et al. 2002; McDonald 2007; Sasal et al. 2010).

We did not find any differences in the diversity of spiders and beetles between nests situated above water or dry ground (spiders: $t_{16}=0.76, P=0.5696$; beetles: $\left.t_{27}=1.44, P=0.1608\right)$. The Shannon-Wiener diversity index was the highest at LC in the case of beetles (avg. Shannon-Wiener $=1.7$; Table 5 ). For spiders the most diverse location was MP1 (avg. ShannonWiener $=1.1$; Table 5). The diversity was lowest for both groups in location SC2 (Table 5). Furthermore, we found that the Shannon-Wiener diversity index of spider and beetle assemblages differed significantly between the five locations (spiders: $t_{4}=3.50, P=0.0248$; beetles: $\left.t_{4}=11.86, P=0.0003\right)$. The arthropod assemblages are capable of great variation from year to year. However, our results are important because as yet there has been no examination of the diversity of nest resident beetle and spider assemblages between different localities where nest-cups were found.

\section{Conclusions}

Studies of beetles resident in nests (Jurík \& Sustek 1978; Šustek \& Jurík 1980; Šustek \& Hornychová 1983; Krištofík et al. 1993, 1994, 2001, 2003, 2005; Sustek \& Krištofík 2002) have been published more frequently than research articles about spiders resident in nests (Gajdoš et al. 1991; Krištofík et al. 1993, 1994). In the case of reed-nesting passerines we lack information about spiders; Gajdoš et al. (1991) mentioned a few species found in nests of reed warbler Acrocephalus scirpaceus Hermann, 1804, and only one in great reed warbler nests. The species composition of both groups varies considerably between the geographical position of our site and the Slovakian study site (Gajdoš et al. 1991; Krištofík et al. 2001). We concluded that a longer duration of nest-use by nestlings or parasitic cuckoo did not result in an increase in the abundance of both tested groups; the species richness of spiders increased with nest use by the birds, whereas with beetles it did not. The amount of precipitation influenced the abundance of spider and beetle assemblages differently from arthropod assemblages not resident in nests. Furthermore, unlike other studies, we found that vegetation cover did not affect the presence of nest inhabiting spider and beetle assemblages. Generally, the diversity of spider and beetle assemblages differed among reed habitats; consequently, we assume reed structure and the surroundings of reed habitats might play an important role in this phenomenon.

\section{Acknowledgements}

The study was supported by the Nature Protection and Study Society - NATURA, Sombor, Serbia. We are grateful to Gyula Szabó and Máté Kisfali for useful comments. Furthermore, we thank to Michael Smart for the linguistically editing of the manuscript.

\section{References}

Antunes S.C., Pereira R., Sousa J.P., Santos M.C. \& Gonçalves F. 2008. Spatial and temporal distribution of litter arthropods in different vegetation covers of Porto Santo Island (Madeira Archipelago, Portugal). Eur. J. Soil Biol. 44 (1): 45-56. DOI: 10.1016/j.ejsobi.2007.08.016

Bang C. \& Faeth S.H. 2011. Variation in arthropod communities in response to urbanization: Seven years of arthropod monitoring in a desert city. Landscape Urban Plan. 103 (3-4): 383-399. DOI: 10.1016/j.landurbplan.2011.08.013

Beier J. 1981. Untersuchungen an Drossel- und Teichrohrsanger (Acrocephalus arundinaceus, A. scirpaceus): Bestandsentwicklung, Brutbiologie, Ökologie. J. Ornithol. 122 (3): 209230. DOI: $10.1007 /$ BF01645337

Bonte D., Leon B. \& Maelfait J.P. 2002. Spider assemblage structure and stability in a heterogeneous coastal dune system. J. Arachn. 30 (2): 331-343.

Carrel J.E. 2001. Population dynamics of the red widow spider (Araneae: Theridiidae). Florida Entomologist $\mathbf{8 4}$ (3): 385-390. http://www.fcla.edu/FlaEnt/fe84p385.pdf (accessed July 2013)

Cramp S. 1998. The Complete Birds of the Western Palearctic. Oxford University Press. (Based on Stanley Cramp's definitive and critically acclaimed nine-volume) Windows CDROM. ISBN: 0192685791, 9780192685797

Dražina T. \& Špoljar M. 2009. Insect fauna in nest of the Eurasian griffon vulture (Gyps fulvus) in Croatia. Biologia 64 (5): 969973. DOI: $10.2478 / \mathrm{s} 11756-009-0147-y$

Đukanović D. 1970. Klima Sombora i okoline. Beograd, 134 pp.

Finnamore A.T., Winchester N.N. \& Behan-Pelletier V.M. 1998. Protocols for Measuring Biodiversity: Arthropod Monitoring in Terrestrial Ecosystems. Biodiversity Science Board of Canada, Ecological Monitoring and Assessment Network (EMAN), Burlington, Ontario, 53 pp.

Fischer S. 1994. Einfluss der Witterung auf den Bruterfolg des Drosselrohrsangers Acrocephalus arundinaceus am Berliner Müggelsee. Vogelwelt 115 (6): 287-292.

Gajdoš P., Krištofík J. \& Šustek Z. 1991. Spiders (Araneae) in the birds nests in Slovakia. Biologia 46 (10): 887-905.

Graveland J. 1998. Reed die-back, water level management and the decline of the Great Reed Warbler Acrocephalus arundinaceus in the Netherlands. Ardea 86 (2): 187-201.

Grimbacher P.S. \& Stork N.E. 2009. Seasonality of a diverse beetle assemblage inhabiting lowland tropical rain forest in Australia. Biotropica 41 (3): 328-337. DOI: 10.1111/j.17447429.2008.00477.x 
Jurík M. \& Šustek Z. 1978. The Coleoptera in nests of Passer domesticus in Czechoslovakia. Vestn. Cesk. Spol. Zool. 17 (4): 255-272.

Krištofík J., Mašán P. \& Sustek Z. 2001. Mites (Acari), beetles (Coleoptera) and fleas (Siphonaptera) in the nests of great reed warbler (Acrocephalus arundinaceus) and reed warbler (A. scirpaceus). Biologia 56 (5): 525-536.

Krištofík J., Mašán P. \& Sustek Z. 2005. Arthropods in the nests of marsh warbler (Acrocephalus palustris). Biologia 60 (2): 171-177.

Krištofík J., Mašán P. \& Šustek Z. 2007. Arthropods (Pseudoscorpionida, Acari, Copleptera, Siphonaptera) in the nests of the bearded tit (Panurus biarmicus). Biologia 62 (6): 749755. DOI: $10.2478 / \mathrm{s} 11756-007-0142-0$

Krištofík J., Mašán P., Šustek Z. \& Gajdoš P. 1993. Arthropods in the nests of penduline tit (Remiz pendulinus). Biologia 48 (5): 493-505.

Krištofík J., Mašán P., Šustek Z. \& Karaska D. 2009. Arthropods in the nests of the lesser spotted eagle (Aquila pomarina). Biologia 64 (5): 974-980. DOI: 10.2478/s11756-009-0148-x

Krištofík J., Mašán P., Šustek Z. \& Kloubec B. 2003. Arthropods (Pseudoscorpionida, Acari, Copleptera, Siphonaptera) in the nests of the tengmalm's owl Aegolius funereus. Biologia 58 (2): 231-240.

Krištofík J., Sustek Z. \& Gajdoš P. 1994. Arthropods in the nests of the Sand Martin (Riparia riparia Linnaeus, 1758) in South Slovakia. Biologia 49 (5): 683-690.

Krištofík J., Šustek Z. \& Gajdoš P. 1995. Arthropods in the penduline tit (Remiz pendulinus) nests: occurrence and abundance in different breeding phases. Biologia 50 (5): 487-493.

la Puente J.M., Lobato S.M.E., Aguilar J.R., del Cerro S., Castañeda R.R. \& Moreno J. 2010. Nest-climatic factors affect the abundance of biting flies and their effects on nestling condition. Acta Oecol. 36 (6): 543-547. DOI: 10.1016/j.actao.2010.07.008

Leisler B. 1981. Die ökologische Einmischung der mitteleuropaischen Rohrsanger (Acrocephalus, Sylviinae). I. Habitattranung. Vogelwarte 31: 45-74.

Logan J.D., Wolesensky W. \& Joern A. 2006. Temperaturedependent phenology and predation in arthropod systems. Ecol. Modell. 196 (3-4): 471-482. DOI: 10.1016/j. ecolmodel.2006.02.034

Majka C.G., Klimaszewski J. \& Lauff R.F. 2006. New Coleoptera records from owl nests in Nova Scotia, Canada. Zootaxa 1194: $33-47$.

McDonald, B. 2007. Effects of vegetation structure on foliage dwelling spider assemblages in native and non-native Oklahoma grassland habitats. Proc. Okla. Acad. Sci. 87: 85-88.

Mérő T.O. \& Žuljević A. 2009. Breeding density and breeding success of the Great Reed Warbler Acrocephalus arundinaceus in Sombor municipality (In Serbian with English summary). Ciconia 18: 91-98.
Nilsson L. \& Persson H. 1986. Choice of nest site, clutch size and nesting success in population of Reed Warbler, Acrocephalus scirpaceus, in South Sweden. Vør Føgelwärld 45 (6): 340346.

Orozco J. \& Perez M. 2008. Coprophagous scarab beetles (Coleoptera, Scarabaeoidea) of Los Estoraques National Park (Norte de Santander, Colombia). Rev. Bras. Entomol. 52 (1): 36-40. DOI: 10.1590/S0085-56262008000100007.

Prokešová J. \& Kocian L. 2004. Habitat selection of two Acrocephalus warblers breeding in reed beds near Malacky (Western Slovakia). Biologia 59 (5): 637-644.

$\mathrm{R}$ Development Core Team 2011. A language and environment for statistical computing. R Foundation for Statistical Computing, Vienna.

Rodrigues E.N.L., Mendonca M.D. \& Ricardo O. 2008. Spider fauna (Arachnida, Araneae) in differents stages of the irrigated rice culture in Cachoeirinha, RS, Brazil. Iheringia Sér. Zool. 98 (3): 362-371. DOI: 10.1590/S007347212008000300011

Sasal Y., Raffaele E. \& Farji-Brener A.G. 2010. Succession of ground-dwelling beetle assemblages after fire in three habitat types in the Andean forest of NW Patagonia, Argentina. J. Insect Sci. 10: 1-17. DOI: 10.1673/031.010.3701

Šustek Z. \& Hornychová D. 1983. The Beetles in the nests of Delichon urbica in Slovakia. Acta Rer. Natur. Mus. Nat. Slov. 29: $119-134$.

Sustek Z. \& Jurík M. 1980. The Coleoptera from the nests of Riparia riparia in Czechoslovakia. Vestn. Česk. Spol. Zool. 44: $286-292$.

Šustek Z. \& Krištofík J. 2002. Beetles (Coleoptera) in deserted nests of Phoenicurus ochruros, Parus caeruleus, Parus major, Sitta europaea, and Sturnus vulgaris. Entomofauna carpathica 14: 64-69.

Sustek Z. \& Krištofík J. 2003. Beetles (Coleoptera) in the nests of house and tree sparrows (Passer domesticus and P. montanus). Biologia 58 (5): 953-965.

Tomić P. 1996. Klima, pp. 16-21. In: Đuričić J. (ed.), Opština Sombor, Prirodno-matematički fakultet, Institut za geografiju, Prosveta, Novi Sad.

Touloumis K. \& Stamou G.P. 2009. A metapopulation approach of the dynamics of arthropods from Mediterraneantype ecosystems. Ecological Modelling 220 (8): 1105-1112. DOI: 10.1016/j.ecolmodel.2009.01.032

van Der Hut R.M.G. 1986. Habitat choice and temporal differentiation in reed Passerines of a dutch marsh. Ardea 74 (2): 159-176.

Received November 25, 2013 Accepted March 7, 2014 